\title{
From Cell to Society
}

Citation for published version (APA):

Brand, A. M. (2009). From Cell to Society. Maastricht University. https://doi.org/10.26481/spe.20090904ab

Document status and date:

Published: 04/09/2009

DOI:

10.26481/spe.20090904ab

Document Version:

Publisher's PDF, also known as Version of record

\section{Please check the document version of this publication:}

- A submitted manuscript is the version of the article upon submission and before peer-review. There can be important differences between the submitted version and the official published version of record.

People interested in the research are advised to contact the author for the final version of the publication, or visit the DOI to the publisher's website.

- The final author version and the galley proof are versions of the publication after peer review.

- The final published version features the final layout of the paper including the volume, issue and page numbers.

Link to publication

\footnotetext{
General rights Owners
rights.

- You may freely distribute the URL identifying the publication in the public portal. please follow below link for the End User Agreement:

www.umlib.nl/taverne-license

Take down policy

If you believe that this document breaches copyright please contact us at:

repository@maastrichtuniversity.nl

providing details and we will investigate your claim.
}

Copyright and moral rights for the publications made accessible in the public portal are retained by the authors and/or other copyright owners and it is a condition of accessing publications that users recognise and abide by the legal requirements associated with these

- Users may download and print one copy of any publication from the public portal for the purpose of private study or research.

- You may not further distribute the material or use it for any profit-making activity or commercial gain

If the publication is distributed under the terms of Article $25 \mathrm{fa}$ of the Dutch Copyright Act, indicated by the "Taverne" license above, 


\section{Maastricht University in Leanumin!}

Department of Social Medicine

Prof. Dr. Angela Brand MD PhD MPH

Head of the Department of Social Medicine

Director of the European Centre for Public Health Genomics (ECPHG)

Inaugural Lecture: "From Cell to Society" (04.09.2009)

The Department of Social Medicine is undergoing substantial changes to meet the requirements of Public Health, health policy making and Public Health Medicine in the future. The ongoing changes in life sciences trigger an integration of all health determinants including genetic factors, or to be more precise, the genome and its interactions with environmental factors. The inaugural lecture outlines how the department will use this change and how it will convert the change into a positive source for research and education. Public Health Genomics is the internationally acknowledged umbrella for this enterprise. Besides Muin Khoury from CDC in Atlanta (USA) and Ron Zimmern from the Public Health Genomics Foundation in Cambridge (UK), Angela Brand had been one of the three pioneers in this field in the world. The concept of Public Health Genomics ensures the effective and responsible translation of innovations "from cell to society". The change we see also implies that Social Medicine and Public Health adjust its methodologies and research approaches, a change which needs to be reflected in the future concept and staff composition of the department of Social Medicine.

\section{Vision of the Department of Social Medicine}

To improve health and prevent diseases by focussing on the highly innovative and cross-cutting approach "Public Health Genomics (PHG)" and by bridging Medicine and Public Health (Public Health Medicine)

\section{Mission of the Department of Social Medicine}


To systematically translate genome-based knowledge and technologies into health research (assessment), health policies (policy development) and healthcare (assurance) on the regional, national, European and international level (Public Health Trias)

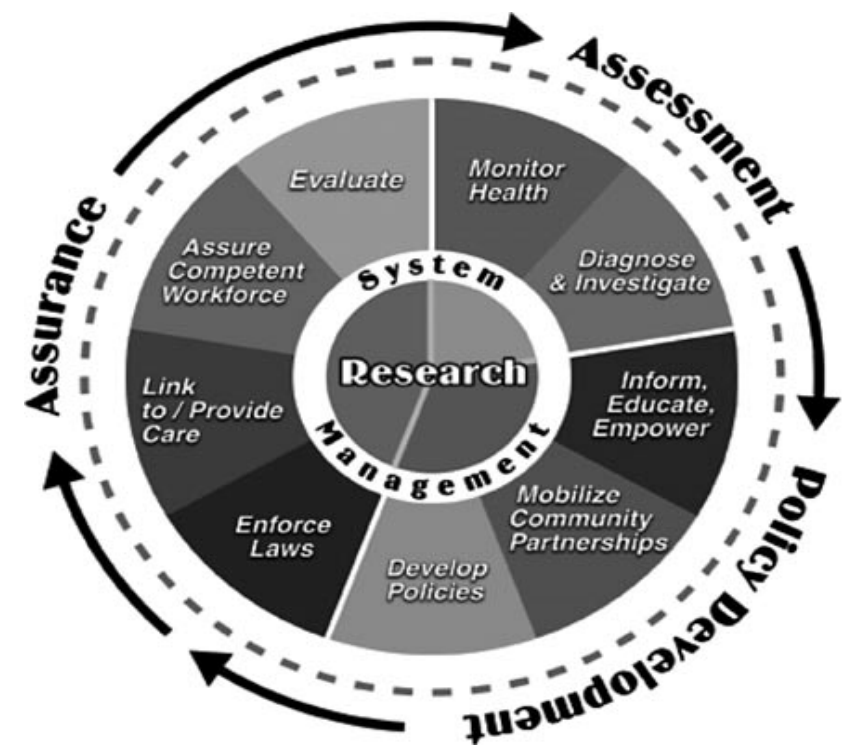

Public Health Trias [CDC, 2001]

\section{Goals of the Department of Social Medicine}

- $\quad$ bridging Medicine, Health and Life Sciences within UM (Public Health Medicine)

- being complementary to the other departments and schools of the FHML within UM

- being of added value to the other departments and schools of the FHML within UM

- integrating PHG systematically into education and research of the FHML within UM

- contributing to the societal impact of the FHML within UM

- contributing strongly to regional, national, European and international visibility through the activities of the European Centre of Public Health Genomics (ECPHG)

- promoting the P4 principle (Predictive, Preventive, Personalized, Participatory Healthcare) through the activities of the ECPHG

- $\quad$ strengthening strategic partnerships with governmental bodies and industry

- valorization through spin-offs related to PHG

There are 4 major strategies to reach these goals:

1. Link with PHGEN (Public Health Genomics European Network) and GRaPH-Int (Genome-based Research and Population Health International Network) = potential to become the leader in PHG not only on the European but also on the global level

2. Link with the UM strategy = potential to become the hub for other departments and schools by serving as a Genomics Resource Centre for knowledge brokering inside $\mathrm{MUMC}^{+}$ 
3. Link with the EU strategy on health in all policies and other European policy frameworks such as the Lisbon Strategy. = potential to become the leader in European policy advice on Public Health Genomics

4. Link with the UM holding = potential for facilitating the valorization process for innovations from inside and outside the university in the field of PHG, in particular in fields such as pharmacogenomics and nutrigenomics

\section{Social Medicine with the innovative profile Public Health Genomics (PHG)}

Traditionally, Social Medicine has always been the bridging medical discipline between medicine and public health. Since 1997 the European Union of the Medical Specialists (UEMS) is strengthening this medical speciality of Public Health in the EU medical specialist system by promoting the harmonization and quality of specialist medical training and practice in Public Health Medicine in the EU countries. Thus, in the Netherlands the Dutch Association of Medical Specialists (de Orde van Medisch Specialisten) already in 2001 described in its blueprint for medical education the knowledge transfer of the whole healthcare chain of primary, secondary and tertiary prevention as a key task of Public Health Medicine (Sociale Geneeskunde).

Social Medicine as a multidisciplinary medical speciality has been very successful in the past by looking at interactions between the different health determinants such as clinical, socioeconomic, demographic, lifestyle, behavioural and environmental determinants of health during the whole life course (e.g., prenatal care, child and youth health, occupational health, health of the elderly). Social Medicine in recent years has been challenged by demographic change, e.g. the aging of the population.

Furthermore, current clinical as well as public health interventions will fail to be effective and efficient, if novel knowledge such as deriving from systems biology, integrative genomics including epigenomics and genome-environmental interactions is not timely and responsibly translated into the healthcare systems. This is true not only for almost all public health interventions such as those regarding obesity, newborn screening, infectious diseases and vaccination or health promotion, but also for almost all medical interventions such as regarding common complex diseases like osteoporosis, cardiovascular diseases, cerebrovascular diseases, cancer and diabetes, which account for $86 \%$ of all deaths and $77 \%$ of burden of disease in Europe (Global Burden of Disease, 2005).

Using Public Health Genomics as the new profile of Social Medicine will allow Maastricht University to have a unique, pioneering as well as highly innovative position in the field of Social Medicine in the Netherlands, in Europe as well as internationally. The matrix structure of the UM, the Problem-Based Learning (PBL) approach, medicine, health and life sciences being already "under one roof" as well as the future life and science campus ("campus hills") with translational research perspectives for Maastricht UMC ${ }^{+}$ provide excellent opportunities to further support the European Centre for Public Health Genomics as the centre of excellence in this field in Europe..

\section{Definition of Public Health Genomics (PHG)}


In 2005 the US Institute of Medicine (IOM) defined Public Health Genomics (PHG) as "an emerging field that assesses the impact of genes and their interaction with behavior, diet and the environment on the population's health". In the same year the international expert group on PHG supported by the Rockefeller Foundation defined PHG as "the responsible and effective translation of genome-based knowledge and technologies into public policy and health services for the benefit of population health" (Bellagio statement, 2005). Angela Brand was member of this international expert group.

The task of public health genomics (PHG) has become a challenge for all healthcare systems having major implications for future research and policy strategies. The various stakeholders in public health play a key role in translating the implications of genomics such as deriving from systems biology, integrative genomics including epigenomics and genome-environmental interactions. Recent advances in systems biology indicate that specific cellular functions are infrequently carried out by single genes, but rather by groups of cellular components. This network-based research ("diseasomes") is already starting to change nosology as well as to challenge population-based genetic screening or epidemiological methods like Health Technology Assessment (HTA). This knowledge will not only enable clinical interventions but also health promotion messages and disease prevention programmes to be targeted at susceptible individuals as well as subgroups of the population based on their genomic profile (personalized healthcare). So far there has been no systematic integration of genome-based knowledge and technologies into public health research, policy and practice. Thus, the public health agenda demands a vision that reaches beyond the research horizon to arrive at application and public health impact of these innovations.

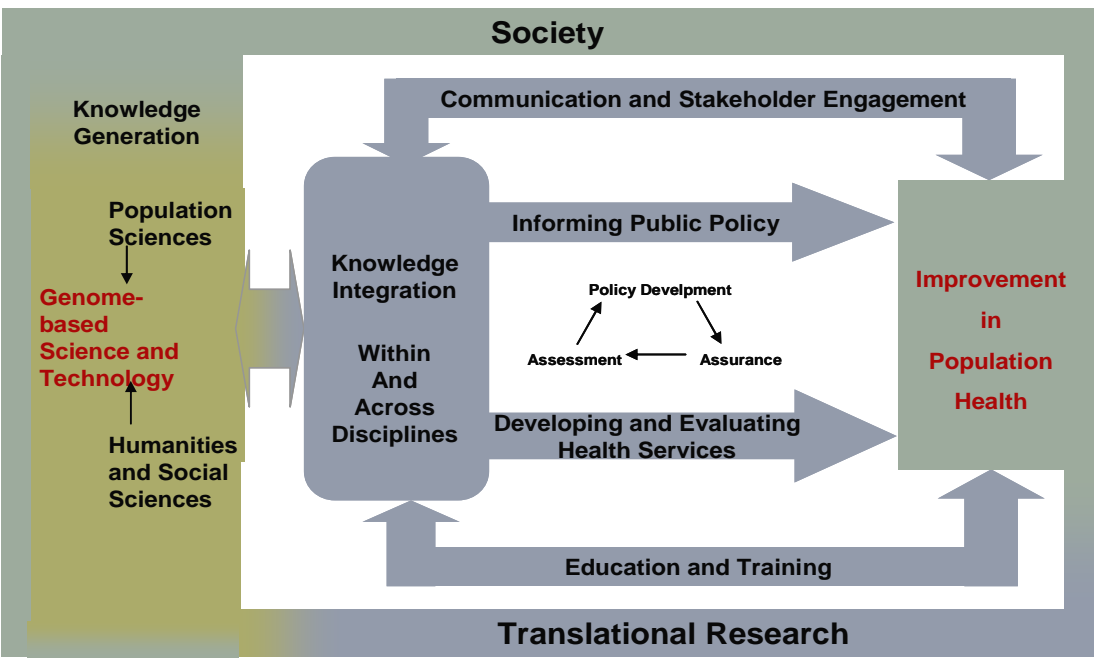

Bellagio model of Public Health Genomics (2005) 


\section{The role of the European Centre for Public Health Genomics (ECPHG)}

The European Centre for Public Health Genomics (ECPHG) (www.ecphg.eu) is the European centre of excellence and "think tank" in the field of Public Health Genomics (PHG) operating on national, European and international level.

Maastricht University in Laming!

Universiteit Maastricht

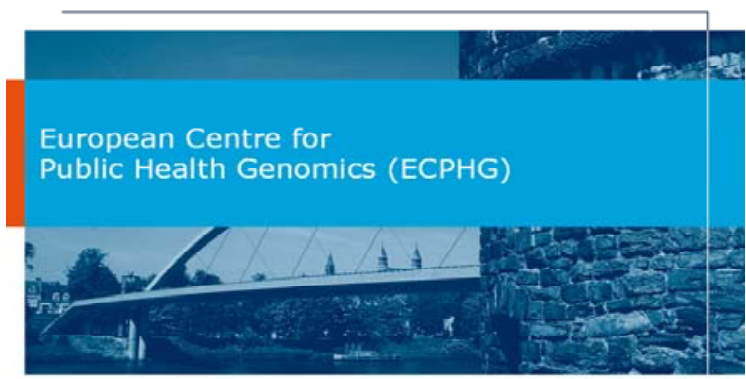

European Centre for Public Health Genomics (ECPHG)

Maastricht University Lesaling Lenning!

Maastricht University 'mLaming!

European Centre for Public Health Genomics (ECPHG)

Main objectives:

(1) Translational research on the integration of genome-based knowledge and technologies into public health research, policy and practice (PHG) through national, European and international activities

2) Systematic horizon scanning, monitoring and surveillance of challenges and tasks of Prealth (Policy Impact

Assessment

ent of health care on the national, European and international level by establishing a knowledge base for evidence-based policy-making and policy esearch

(4) Interdisciplinary and inter-institutional research, health policy analysis and training

(5) Holding meetings open to the scientific community, policy-makers, relevant stakeholders and the general public

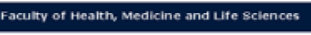




\section{The ECPHG}

- coordinates the Public Health Genomics European Network (PHGEN www.phgen.eu) involving competent authorities from all European Member States, EFTA-EEA and Applicant Countries

- has a collaboration agreement with the Institute for Prospective Technology Studies (IPTS) in Spain, which is one of the seven Joint Research Centers (EC-JRC) of the European Commission

- is running the international journal "Public Health Genomics" with Karger publishers (www.karger.com/phg)

- is leading the section on PHG within the European Public Health Association (EUPHA)

- will soon be the administrative hub of the international network GRaPHint (Genomebased Research and Population Health)

- will become WHO Collaborating Centre in PHG (in negation phase)

- is member of the international consortium on the harmonization of biobanking $\mathrm{p} 3 \mathrm{~g}$ (Public Population Projects in Genomics)

- has established 16 national centres on PHG such as the GENAR institute in Turkey

- is partner in various European and international projects like MUTANOM; EuroGentest, APOGEE/GeneTest Canada, EUREGIO, NuGO, EUnetHTA (European Network on Health Technology Assessment), DataProBio, BBMRI, EpiGenChlamydia Consortium

- collaborates with European and international institutions such as the Max Planck Institute (MPI) on Molecular Genetics in Berlin/Germany, the Personal Genome Project at Harvard Medical School, the Public Health Agency Canada, the National Office of PHG at the CDC Atlanta, the European Centres for Disease Prevention and Control (ECDC), the European Observatory on Health Systems and Policies of WHO in Brussels, INSERM France

- collaborates with industry (e.g., Roche Personalized Healthcare, Baxter, Bayer HealthCare)

- has been involved in producing policy statements for institutions such as the Council of Europe, the OECD, the European Science Foundation (ESF), the ECDC, the National Competent Authorities (NCAs) of the EU, the EU on the Health Strategy, the EMEA on Medical Devices

- $\quad$ promotes spin offs such as ALACRIS Pharmaceuticals or GENAR Gentest 


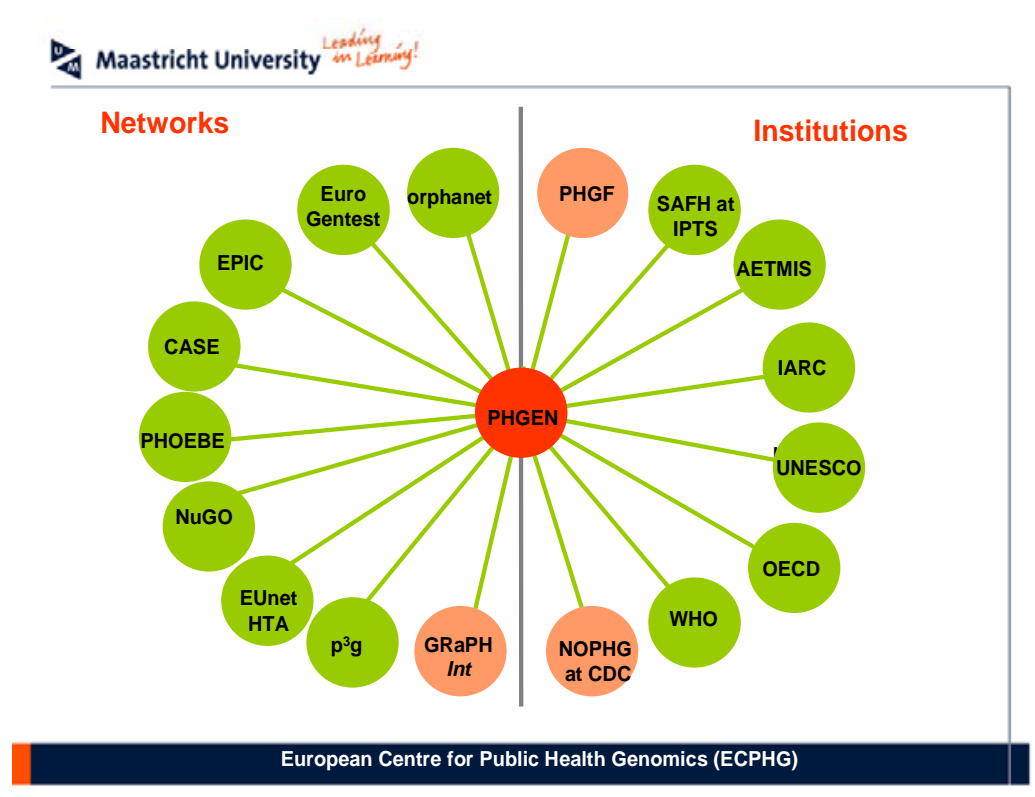

PHGEN Network of Networks and Institutions (2009)

The coordination of the Public Health Genomics European Network (PHGEN) is one of the current key activities of the ECPHG. PHGEN is funded by the General Directorate for Health and Consumer Protection (DG SANCO) under the Health Programme of the EU. PHGEN II produces the 1st edition of "European Best Practice Guidelines for Quality Assurance, Provision and Use of Genome-based Information and Technologies", which assist all Member States, Applicant Countries and EFTA-EEA Countries and will strongly contribute to the reduction of the burden of disease in Europe. It involves key experts such as Public Health experts, EU lawyers, Geneticists, Ethicists, Systems Biologists, HTA experts, patient groups and competent authorities. Expertise from networks like EuroGentest, EUnetHTA, NuGO is provided to assess existing guidelines, identify gaps and set up a coherent, evidence-based framework for quality assurance, provision and use of genome-based information and technologies. PHGEN II is the follow-up of PHGEN I (DG SANCO 2006-2008). Whereas PHGEN I was a "mapping exercise", PHGEN II systematically builds on the work of PHGEN I. It uses the concept of "genome-based information and technologies" (Bellagio-Model) which PHGEN I established as a scientific benchmark in Europe. While protecting human rights, equity in healthcare and solidarity amongst citizens, it meets the Lisbon Agenda objectives and values of the Health Strategy. 


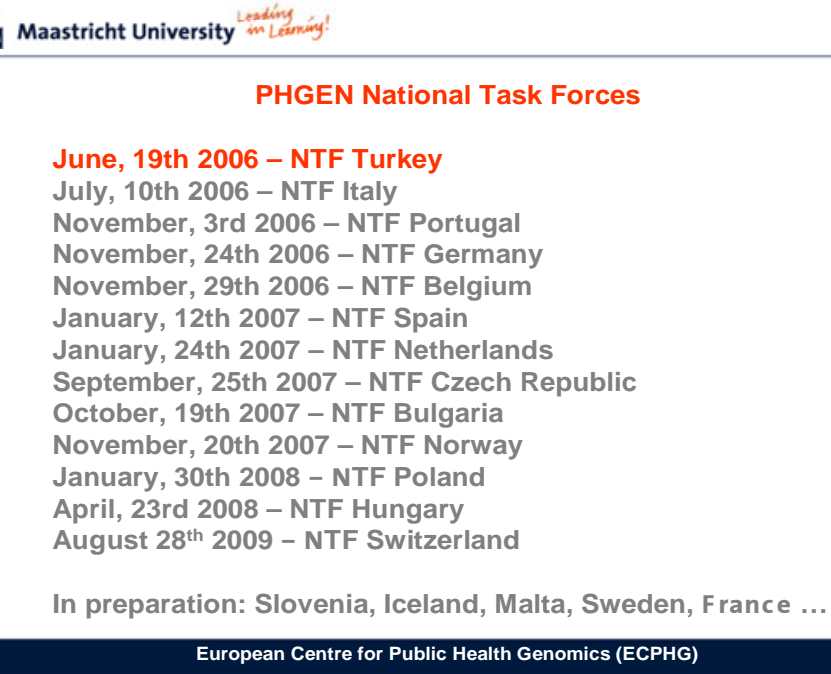

European Centre for Public Health Genomics (ECPHG)

PHGEN National Task Forces (2009)

„In the long run PHGEN will serve the European Commission as an ,early detection unit" (European observatory on PHG) for horizon scanning, fact finding, and monitoring of the integration of genome-based knowledge and technologies into public health."

The European Centre for Public Health Genomics (ECPHG) has already a high European and international visibility and reputation as the centre of excellence in this field in Europe. Internal as well as external support ensures not only to be able to keep that leading position but also to further develop that field. 